\title{
Water source protection and industrial development in the Shandong Peninsula, China from 1995 to 2004: A case study
}

\author{
Bofu Zheng ${ }^{\mathrm{a}, \mathrm{c}}$, Qinghai Guo ${ }^{\mathrm{a}}$, Yuansong Wei ${ }^{\mathrm{b}, *}$, Hongbing Deng ${ }^{\mathrm{a}}$, Keming Ma ${ }^{\mathrm{a}}$, \\ Junxin Liu ${ }^{b}$, Jingzhu Zhao ${ }^{a}$, Xingshan Zhang ${ }^{d}$, Yu Zhao ${ }^{d}$ \\ a State Key Laboratory of Urban and Regional Ecology, Research Center for Eco-Environmental Sciences, Chinese Academy of Sciences, P.O. Box 2871, Beijing 100085, PR China \\ ${ }^{\mathrm{b}}$ Department of Water Pollution Control Technology, Research Center for Eco-Environmental Sciences, Chinese Academy of Sciences, P.O. Box 2871, Beijing 100085, PR China \\ ${ }^{c}$ College of Environmental Science and Engineering, Nanchang University, 339 Beijing East Road, Nanchang 330029, PR China \\ ${ }^{\mathrm{d}}$ Weifang Institute of Environmental Engineering, Weifang 261041, Shandong Province, PR China
}

\section{A R T I C L E I N F O}

\section{Article history:}

Received 17 March 2006

Received in revised form 17 February 2008

Accepted 28 April 2008

Available online 24 June 2008

\section{Keywords:}

Industrial development

Industrial wastewater

Water quality

Water source

\begin{abstract}
A B S T R A C T
Xiashan Reservoir is the largest reservoir in the Shandong peninsula and the major water supply source for urban, industry and agriculture in Weifang, Shandong Province. In the upstream region of Xiashan Reservoir, its industry development ranged in the top three among 12 districts and counties of Weifang from 1995 to 2004. This study investigated changes of water quality in Xiashan Reservoir and its upstream rivers, and analyzed the key industrial developments and industry structure in the upstream region of Xiashan Reservoir between 1995 and 2004, in order to provide potential implications for planning and conducting Xiashan Reservoir protection and the industry development in the upstream region in the future. Five key industries in the upstream region were investigated between 1995 and 2004, including industrial production, water usage, wastewater treatment, and the discharged pollutants. Results showed that the water quality of Xiashan Reservoir gradually improved between 1995 and 2004 and met the requirements of Class III in 2004. Industrial development in the upstream region has increased nearly 7 times, from US\$163.67 million in 1995 to US\$ 1283.69 million in 2004, and shifted in the past decade from food brewery processing industry as the major industry in 1995 to car manufacture and accessory processing as the major industry in 2004. The amounts of water used by the five key industries in 2004 were lower than that in 1995 because of improvements in water utilization and a shift in industry structure. Correspondingly, the total industrial wastewater discharged changed little from 1995 to 2004, but the total $\mathrm{COD}_{\mathrm{Cr}}$ discharged was greatly reduced.
\end{abstract}

(c) 2008 Elsevier B.V. All rights reserved.

\section{Introduction}

Water is vital for the life and health of people and ecosystems, and a basic requirement for economic development. Reliable water supply and the protection of aquatic resources through adequate water management are essential to support all aspects of human life (Abu-Zeid, 1998; The Second World Water Forum, 2000; Zhou and Richard, 2004; Janosova et al., 2006). Together with the most populous country in the world, the impact of China's fast economic development is rapidly increasing on both local and global environment problems (De Groot et al., 2004; Liu and Diamond, 2005). Its rapid urbanization, industrialization, growing agricultural demand, environmental degradation, and potential climate-related threats will be the major driving forces that challenge the management

\footnotetext{
* Corresponding author. Tel.: +86106292 3543; fax: +86 1062849108.

E-mail address: yswei@rcees.ac.cn (Y.Wei).
}

and utilization of China's water resources. China faces great waterrelated challenges throughout the country in the very future, and the problems are particularly acute in the dry north, north of the Yangtze River Basin, and has three major water issues: water shortages, flooding and water pollution (Varis and Vakkilainen, 2001; Wang, 2003; World Bank Report, 2003). Over-exploitation and over-use of water resources, along with increasing water pollution in many parts of the country, especially in northern China, are contributing to the decline and deterioration of water resources and damage to freshwater and coastal environments. Inadequate water resources and water pollution in northern China has been a serious constraint to regional socioeconomic development, and consequently, has slowed development and become an obstacle to the implementation of the country's sustainable development plan (Liu and Chen, 2001; Li et al., 2003; Wang et al., 2004). In the almost 500 sections of China's main river systems that are monitored for water quality, about one-third have water quality with very limited or no functional use, and only $28 \%$ have water suitable for 
drinking. A thorough review of all monitoring data over a 15 -year period (made available by China's National Monitoring Center) reveals that there are hardly any improvements, particularly in the most critical rivers in the North. The core fact is that in the North, $40-60 \%$ of the region's water is continuously in the non-functional water classification categories (World Bank Report, 2006).

Source water protection, as important as effective water treatment, is recognized as the first barrier in a multi-barrier approach to provide reliable water supplies. For surface water (e.g., lakes, reservoirs, rivers), source water protection typically takes the form of watershed management, while for groundwater resources efforts may focus on private wells, municipal water fields, groundwater recharge areas, or whole aquifers. Institutional arrangements for land use planning and water resource management, in particular, are key determinants shaping capacity for source water protection. Institutional arrangements include legislation and regulations, policies and guidelines, administrative structures, economic and financial arrangements, and political structures and processes (Clark et al., 1998; National Research Council, 2000; Pionke et al., 2000; Pires, 2004; Postel and Thompson, 2005; Sullivan et al., 2005; Ivey et al., 2006a,b; Timmer et al., 2007). The approach to source water protection in a particular locale is different, e.g., the City of New York, with large upland water reservoirs, is aggressively pursuing the proactive watershed management approach in which land use policy plays a central role in providing the public with a safe and reliable water supply. While in contrast, the City of Cincinnati, which uses the Ohio River as its source has spent millions of dollars in state-of-the-art water treatment (Clark et al., 1998; Pires, 2004).

The importance of source water protection and water resource management is well recognized and considered a priority by the Chinese government, in particular, source water protection is becoming more and more challenging because of rapid growth in water demand and serious water pollution caused by rapid economic development (MWR, 2001, 2004, 2005). In the water sources for 38 major cities monitored three times a month by the Ministry of Water Resources since April 1999 (Tang and Wang, 2001; Du and Peng, 2004), data showed that the water quality of most of these major water sources was stable and met national quality standards of surface water (GB3838-2002) and ground water (GB T 14848-93), but the levels of ammonia nitrogen, permanganate salt $\left(\mathrm{COD}_{\mathrm{Mn}}\right)$ and volatile hydroxybenzenes in surface water sources exceeded the set standards resulting from severe industrial and domestic pollution in these cities. However, there exist severe flaws in source water protection and water resource management of China as follows: (1) the incomplete and complicated regulatory system results in lack of integration and efficiency in implementation and enforcement, though China government has enacted many laws and regulations for water source protection and water resource management, e.g., the Water Pollution Control Law (1984), the Water Law (2002) and the Cleaner Production Promotion Law (2003); (2) there is often a lack of horizontal and vertical coordination at the institutional level; (3) although investments in water resource management are currently on the rise, there are still insufficient because significant gains in water supply and effective water pollution management will require substantial financial investments (Du and Peng, 2004; World Bank Report, 2006).

Source water protection can limit economic development in the upstream region of the water sources, especially industrial development (Wang and Pan, 1999; Falkenmark, 2000; Zhang et al., 2002; Xu et al., 2003; Du and Peng, 2004; Zhu and Ruan, 2004). For example, the industrial development of areas around Guanting and Miyun Reservoirs, the water supply sources for Beijing, is strongly limited leading to very low growth in GDP for Yanqing and Miyun Counties among counties and districts of Beijing
(Du and Peng, 2004). Thus it is important to balance economic development of water source areas and source water protection in order to realize sustainable development of water source regions.

As the largest reservoir in Shandong peninsula, Xiashan Reservoir in the center of the Weifang area is the major water source for urban, industrial and agricultural development in Weifang city and five other counties (Fangzi, Hanting, Changyi, Gaomi and Haihua). The population of this area is more than three million, and the available irrigated area is around $69.3 \times 10^{3}$ ha. Due to a serious shortage of water in Weifang, i.e. only $350 \mathrm{~m}^{3}$ per capita, much lower than those in China $\left(2220 \mathrm{~m}^{3}\right.$ per capita) and in the world (7450 $\mathrm{m}^{3}$ per capita) (Li and Zhao, 2003), many regulations are in practice for source water protection. Obviously, protecting Xiashan Reservoir is important in providing a stable and clean water supply for Weifang's sustainable development.

The upstream region of Xiashan Reservoir includes Zhucheng County and Jingzhi Town of Anqiu County, Zhuncheng has emerged as a new city since 1980, with rapid socioeconomic development, i.e. a threefold increase in GDP (gross domestic product) between 1980 and 1996. In 2004, Zhucheng County accounted for 93\% of the area, $91 \%$ of the population and $96 \%$ of the industrial production in the upstream region of Xiashan Reservoir, respectively (Weifang Statistics Bureau, 2005).Zhucheng County therefore plays a significant role in protecting Xiashan Reservoir. Due to rapid socioeconomic development in the past decade, industrial development in Zhucheng County may pose a potential threat to safe water usage and the Xiashan Reservoir. Local governments and individuals pay more attention to protection of the Xiashan Reservoir, i.e. introducing measures and regulations to treat industrial pollution sources and limit development of some industries such as pulp and paper making, printing and dyeing and chemical engineering, which pose large potential threats to water bodies (Wang et al., 2005b).

However, industrial development is needed for local socioeconomic development in the upstream region of Xiashan Reservoir. As an important aspect of institutional arrangements, suitable economic and financial arrangements are helpful for source water protection. Hence it is necessary to attempt to harmonize industrial development with source water protection for the future. The target of this study is to investigate changes in water quality in Xiashan Reservoir and its upstream rivers, and analyzed industrial development and shift in industrial structure in the upstream region between 1995 and 2004, in order to provide potential implications for planning and conducting Xiashan Reservoir protection and industrial development in the upstream region in the future. The environmental Kuznets curve (EKC) is a hypothesized relationship between various indicators of environmental degradation and income per capita. In this study, a standard EKC model (Stern, 2004) is introduced to primarily examine the industrial development-environment relationship in the upstream region of Xiashan Reservoir.

\section{Methods}

\subsection{Study area}

As shown in Fig. 1, the study area is located between $118.82^{\circ}-119.70^{\circ} \mathrm{E}$ and $35.78^{\circ}-36.46^{\circ} \mathrm{N}$, including Xiashan Reservoir and its upstream region. The Yellow River to Qingdao Transfer Project, connecting with the Yellow River to Xiashan Reservoir Transfer System (Fig. 1), is the only project for transfer of water diverted from Yellow River basin to the cities of the Shandong peninsula. Xiashan Reservoir plays an important role in water transfer and storage. Hence, the water from Xiashan Reservoir can be 


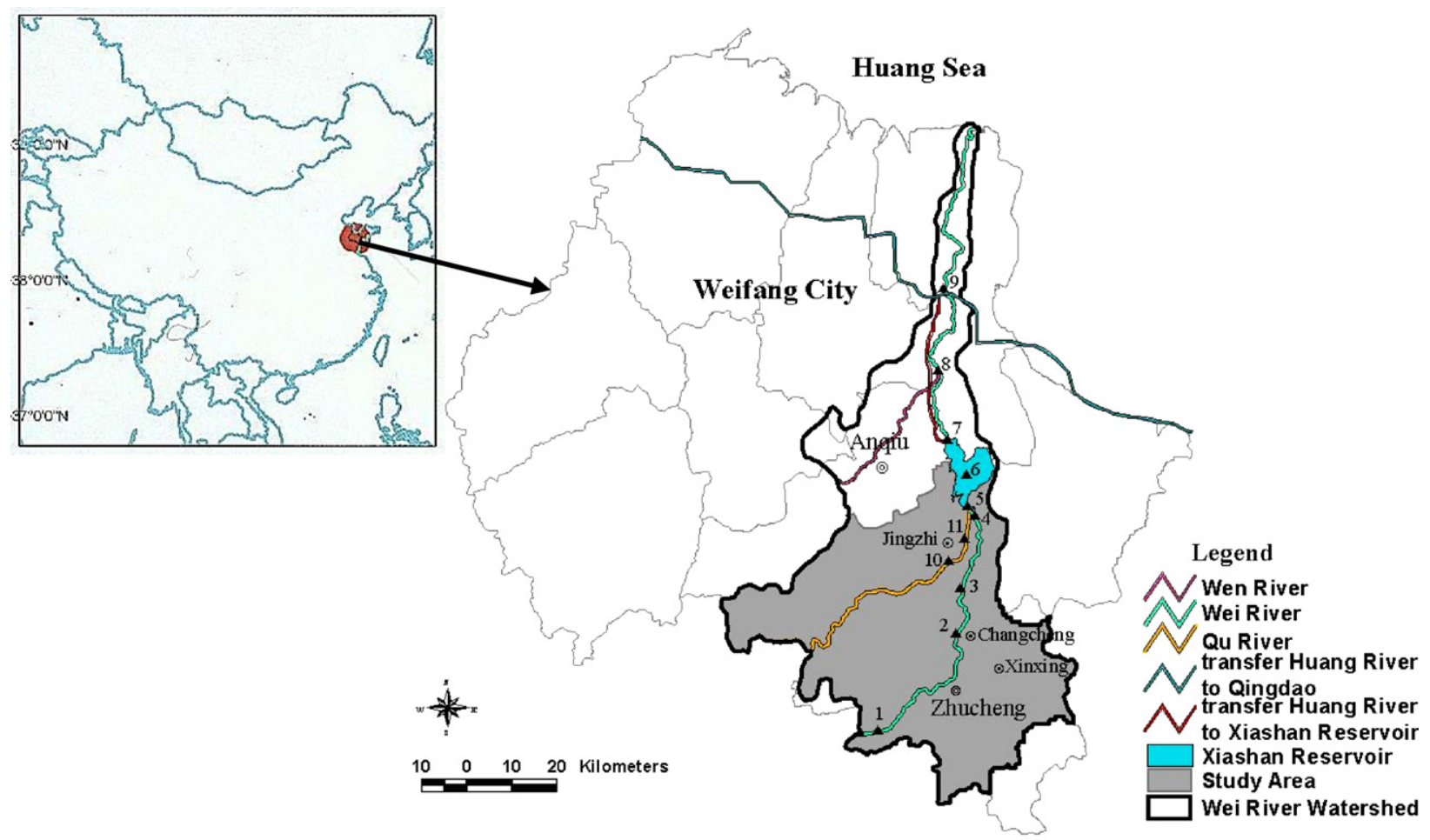

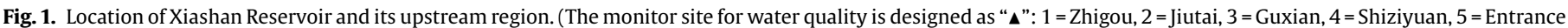
of Xiashan Reservoir, 6 = Middle of Xiashan Reservoir, 7 = Exit of Xiashan Reservoir, 8 = Huicun, 9 = Jinkouba, $10=$ Pengwangdianzi, 11 = Jiagezhuang).

transferred to users in the north through the Yellow River to Xiashan Water Transfer Project, meanwhile water from the Yellow River to Qingdao Water Transfer Project can be stored in Xiashan Reservoir for later use.

In 2004, the upstream region of Xiashan Reservoir had $2347 \mathrm{~km}^{2}$ of total area, 1.163 million of total population and US $\$ 4.17$ billion ( 1 US\$ $=8.273 \mathrm{RMB}$ ) of total industrial production (at current prices), respectively. In 2004, Zhucheng County, including 23 towns and districts, had an area of $2183 \mathrm{~km}^{2}$ and a population of 1.05 million, respectively. Industry played a more and more important role in promoting local socioeconomic development of Zhucheng County from 1994 to 2004 (Table 1), i.e. industry increased from $43.1 \%$ in 1994 to nearly $60 \%$ of total GDP in 2004 , and the urban population increased from $7.8 \%$ in 1994 to $28.7 \%$ of total population in 2004 (Weifang Statistics Bureau, 1995, 2005). Both the GDP and annual growth rate of GDP in Zhucheng from 1994 to 2004 were in the top three of 12 counties and districts of Weifang. The growth rates of GDP and value-added industrial production (at current price) in
Table 1

Population and economic development of Zhucheng County between 1994 and 2004

\begin{tabular}{lrrr}
\hline & \multicolumn{2}{l}{ Year } \\
\cline { 2 - 4 } & \multicolumn{1}{l}{1994} & \multicolumn{1}{c}{2000} & \multicolumn{1}{c}{2004} \\
\hline Population (10 ${ }^{3}$ person) & 1032.7 & 1057.3 & 1061.5 \\
Urban (\%) & 7.8 & 15.8 & 28.7 \\
Rural (\%) & 92.2 & 84.2 & 71.3 \\
GDPa (106 US\$) (at current price) & 622.4 & 1056.8 & 2131.8 \\
Agriculture (\%) & 28.8 & 22.8 & 14.8 \\
Industry (\%) & 43.1 & 47.2 & 59.5 \\
Service (\%) & 28.1 & 30.0 & 25.7 \\
\hline
\end{tabular}

a 1 US\$ $=8.273 R M B$.

Zhucheng County between 1994 and 2004 were higher (13.1\% and $16.8 \%$ ) than that $(11.5 \%$ and $13.7 \%)$ of Weifang, respectively.

The catchment area of Xiashan Reservoir is $2285 \mathrm{~km}^{2}$ and the total capacity of Xiashan Reservoir is $1405.0 \times 10^{6} \mathrm{~m}^{3}$, but the rainfall is very low, only $673.9 \mathrm{~mm} / \mathrm{year}$. The two main upstream rivers

Table 2

Classification of surface water environmental function area in Wei River, Qu River and Xiashan Reservoir

\begin{tabular}{|c|c|c|c|c|c|c|}
\hline No. & Monitor site & River & Water area & Length $(\mathrm{km})$ & Function area & Water quality planned ${ }^{a}$ \\
\hline 1 & Zhigou & Wei River & $\begin{array}{l}\text { Exit of Qiangkuang } \\
\text { Reservoir-Guanzhuang }\end{array}$ & 28.0 & Agricultural water & IV \\
\hline 2 & Jiutai & Wei River & Guanzhuang-jiutai & 11.0 & Agricultural water & V \\
\hline 3 & Guxian & Wei River & Jiutai-Guxian Dam & 12.0 & Agricultural water & IV \\
\hline 4 & Shiziyuan & Wei River & Guxian Dam-Shiziyuan & 18.8 & Agricultural water & III \\
\hline $5,6,7$ & $\begin{array}{l}\text { Entrance, middle and } \\
\text { exit of Xiashan } \\
\text { Reservoir }\end{array}$ & Wei River & $\begin{array}{l}\text { Shiziyuan-exit of Xiashan } \\
\text { Reservoir }\end{array}$ & 18.0 & Drinking water & II \\
\hline 8 & Huicun & Wei River & $\begin{array}{l}\text { Exit of Xiashan } \\
\text { Reservoir-Huicun Dam }\end{array}$ & 14.0 & Agricultural water & III \\
\hline 9 & Jinkouba & Wei River & Huicun Dam-Xing'anzhuang & 54.0 & Agricultural water & III \\
\hline 10 & Pengwangdianzi & Qu River & Headstream-Heyacun & 76.3 & Agricultural water & III \\
\hline 11 & Jiagezhuang & Qu River & Heyacun-Xiashan Reservoir & 8.0 & Agricultural water & III \\
\hline
\end{tabular}

a The water quality planned is on the basis of the national standard "GB3838-2002". 
Table 3

Standard of surface water environmental quality (GB3838-2002) (mg/L)

\begin{tabular}{|c|c|c|c|c|c|c|}
\hline Parameter & & Class I & Class II & Class III & Class IV & Class V \\
\hline DO & $\geq$ & 7.5 & 6 & 5 & 3 & 2 \\
\hline $\mathrm{COD}_{\mathrm{Mn}}$ & $\leq$ & 2 & 4 & 6 & 10 & 15 \\
\hline $\mathrm{COD}_{\mathrm{Cr}}$ & $\leq$ & 15 & 15 & 20 & 30 & 40 \\
\hline $\mathrm{BOD}_{5}$ & $\leq$ & 3 & 3 & 4 & 6 & 10 \\
\hline $\mathrm{NH}_{3}-\mathrm{N}$ & $\leq$ & 0.15 & 0.5 & 1.0 & 1.5 & 2.0 \\
\hline $\mathrm{TP}^{\mathrm{a}}$ & $\leq$ & $0.02(0.01)$ & $0.1(0.025)$ & $0.2(0.05)$ & $0.3(0.1)$ & $0.4(0.2)$ \\
\hline TN (Lake, Reservoir) & $\leq$ & 0.2 & 0.5 & 1.0 & 1.5 & 2.0 \\
\hline $\mathrm{Cu}$ & $\leq$ & 0.01 & 1.0 & 1.0 & 1.0 & 1.0 \\
\hline $\mathrm{Zn}$ & $\leq$ & 0.05 & 1.0 & 1.0 & 2.0 & 2.0 \\
\hline Fluoride & $\leq$ & 1.0 & 1.0 & 1.0 & 1.5 & 1.5 \\
\hline $\mathrm{Se}$ & $\leq$ & 0.01 & 0.01 & 0.01 & 0.02 & 0.02 \\
\hline As & $\leq$ & 0.05 & 0.05 & 0.05 & 0.1 & 0.1 \\
\hline $\mathrm{Hg}$ & $\leq$ & 0.00005 & 0.00005 & 0.0001 & 0.001 & 0.001 \\
\hline $\mathrm{Cd}$ & $\leq$ & 0.001 & 0.005 & 0.005 & 0.005 & 0.01 \\
\hline $\mathrm{Cr}^{6+}$ & $\leq$ & 0.01 & 0.05 & 0.05 & 0.05 & 0.1 \\
\hline $\mathrm{Pb}$ & $\leq$ & 0.01 & 0.01 & 0.05 & 0.05 & 0.1 \\
\hline Cyanide & $\leq$ & 0.005 & 0.05 & 0.2 & 0.2 & 0.2 \\
\hline Volatile hydroxybenzene & $\leq$ & 0.002 & 0.002 & 0.005 & 0.01 & 0.1 \\
\hline Oil & $\leq$ & 0.05 & 0.05 & 0.05 & 0.5 & 1.0 \\
\hline Anion active surfactant & $\leq$ & 0.2 & 0.2 & 0.2 & 0.3 & 0.3 \\
\hline Sulfide & $\leq$ & 0.05 & 0.1 & 0.05 & 0.5 & 1.0 \\
\hline Feces coliform (No./L) & $\leq$ & 200 & 2000 & 10,000 & 20,000 & 40,000 \\
\hline
\end{tabular}

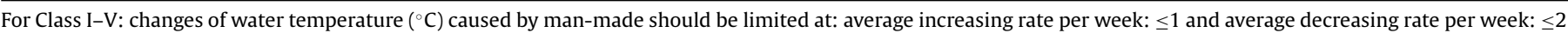
pH 6-9.

a The value in parenthesis is for lake and reservoir.

of Xiashan Reservoir are the Wei and Qu Rivers, which are both seasonal with remarkable flow variation between high and low water periods. The annual water input to Xiashan Reservoir from these two rivers is from 750 million $\mathrm{m}^{3}$ to 850 million $\mathrm{m}^{3}, 50 \%$ from Wei River and about 30\% from Qu River. Due to interception by river barrages and increasing water demand caused by socioeconomic development in the upstream regions, the amount of water from the Wei and Qu Rivers is gradually decreasing, and sometimes there is no water flow.

\subsection{Monitor sites}

Eleven water quality monitoring sites were set up as local environmental monitoring stations along with the Wei River, Qu River and Xiashan Reservoir (Fig. 1). Only two monitoring sites (Site 8 Huicun and Site 9 Jinkouba) are downstream of Xiashan Reservoir, the other nine monitoring sites are upstream (Table 2, based on the "Classification of surface water environmental function area in Weifang", issued by Weifang government in 2003). According to the regulations, the water quality of Xiashan Reservoir is classified as II. The water quality of upstream monitoring site Shiziyuan, Pengwangdianzi, and Jiagezhuang is classified as III, and that of Zhigou and Guxian as IV, and Jiutai as V. The urban area of Zhucheng County is between Site 1 (Zhigou) and Site 2 (Jiutai), and Jingzhi Town is near Jiagezhuang (Site 11). In addition, a big brewery built in 1948 producing liquor is in Jingzhi Town of Anqiu County. Between $119^{\circ} 14^{\prime} 36^{\prime \prime} \mathrm{E}$ and $36^{\circ} 29^{\prime} 20^{\prime \prime} \mathrm{N}$ (up to Site 2 Jiutai), a new municipal wastewater treatment plant (WWTP) adopting the BIOLAK process from Germany, started running in April 2004, with a design capacity of $66,000 \mathrm{~m}^{3} / \mathrm{d}$ and a practical capacity of $60,000 \mathrm{~m}^{3} / \mathrm{d}$. In 2004 , $60 \%$ of wastewater entered the WWTP were industrial sources.

\subsection{Key industries}

Key manufacturing industries in the upstream region of Xiashan Reservoir are cars and accessory processing (CAP), food processing and brewing (FPB), knitting and clothing (KC), paper making $(\mathrm{PM})$, and chemical engineering (CE). In this study, the top 19 plants from these five industries were selected for analysis on the basis of the industrial production, amounts of water usage and wastewater discharged. In 2004, these 19 plants accounted for 30\% of total industrial production, $29 \%$ of total water usage, and over $75 \%$ of industrial wastewater and $\mathrm{COD}_{\mathrm{Cr}}$ discharged. Except for one brewery in Jingzhi Town, all other 18 plants are in Zhucheng County. Among these 19 key plants, there are 8 FPB plants, 3 CE plants, 3 CMAP plants, $3 \mathrm{KCM}$ plants and 2 PM plants.

\subsection{Data acquisition and analysis}

Monitoring data for water quality in the Wei River, Qu River and Xiashan Reservoir between 1995 and 2004 were collected from local governments, as were the data for industrial production, amounts of water usage and wastewater discharged for these 19 plants.

On the basis of data collected from the Weifang Environmental Protection Agency between 1995 and 2004, a total of 30 parameters from different monitoring sites at different water periods were analyzed according to two national water environmental quality standards, GB3838-88 and GB3838-2002. These parameters are water temperature, suspended solids (SS), total hardness, $\mathrm{pH}$ value, dissolved oxygen (DO), $\mathrm{COD}_{\mathrm{Mn}}, \mathrm{COD}_{\mathrm{Cr}}, \mathrm{BOD}_{5}$, ammonia nitrogen, total nitrogen, total phosphorus, fluoride, cyanide, sulfides, volatile hydroxybenzene, oil, anion active surfactants, $\mathrm{Cu}, \mathrm{Zn}, \mathrm{Se}, \mathrm{As}, \mathrm{Hg}, \mathrm{Cd}$, $\mathrm{Cr}^{6+}, \mathrm{Pb}$, chloride, electrical conductivity (EC), fecal coliform bacteria, transparency and $\alpha$-chlorophyll. Due to replacement of the old standards of GB3838-88 by the new standards of GB3838-2002 in June 1, 2002 (SEPA, 2002), the water quality of monitoring sites in the Wei River, Qu River and Xiashan Reservoir between 1995 and 2004 were analyzed by a single factor index method according to the environmental quality standards of surface water (GB38382002). Therefore, 24 parameters (Table 3 ) were analyzed in this study for evaluating the water quality of Wei River, Qu River and Xiashan Reservoir using the following equation:

$S_{i j}=\frac{C_{i j}}{C_{s i}}$

where $C_{i j}$ is the determined concentration of $i$ pollutant at $j$ site, $\mathrm{mg} / \mathrm{L} ; C_{s i}$ is the standard value of $i$ pollutant, $\mathrm{mg} / \mathrm{L}$. 
On the basis of Statistics Yearbook of Weifang, the discharged industrial wastewater is classified as industrial wastewater discharge and industrial wastewater qualified discharge which meets with requirements of Integrated Wastewater Discharge Standard (GB8978-1996). Due to incomplete data of industrial water use, a standard EKC model expressed as a quadratic function of the level of income (Stern, 2004) is introduced in this study to statistically verify the Kuznets curve relationship between the total discharged industrial wastewater and income observed in the upstream region of Xiashan Reservoir. The general form of the model is expressed as following:

$\ln \left(\frac{E_{t}}{P_{t}}\right)=a_{0}+a_{1} \ln \left(\frac{\mathrm{GDP}_{t}}{P_{t}}\right)+a_{2}\left[\ln \left(\frac{\mathrm{GDP}_{t}}{P_{t}}\right)\right]^{2}$

where $E_{t}$ is total quantity of industrial wastewater discharge (IWD) or industrial wastewater qualified discharge (IWQD) in year $t, \mathrm{~m}^{3}$; $P_{t}$ is population size in year $t$; GDP is gross domestic production in year $t$, US\$. If the regression coefficient $a_{2}$ is negative, Eq. (2) corresponds to the standard EKC model.

\section{Results}

\subsection{Water quality between 1995 and 2004}

\subsubsection{Xiashan Reservoir}

Although the water quality of Xiashan Reservoir is classified as II for drinking water (Table 2), it never met this requirement between 1995 and 2004, and only reached Class III in 2004 (Table 4 and Fig. 2). Between 1995 and 2004, the main parameters exceeded were TN, TP, $\mathrm{COD}_{\mathrm{Mn}}, \mathrm{COD}_{\mathrm{cr}}$, and $\mathrm{BOD}_{5}$, which was characterized by a combination of organic, nutrients (nitrogen and phosphorus) pollution. However, the water quality of Xiashan gradually improved on the basis of $\mathrm{COD}_{\mathrm{cr}}, \mathrm{BOD}_{5}$, TN and TP (Fig. 2). The $\mathrm{COD}_{\mathrm{Cr}}$ and $\mathrm{BOD}_{5}$ in the middle of Xiashan Reservoir in 2004 met Class II, but TN and TP were much higher than limitation values of Class II. Since 2003, two parameters, transparency and $\alpha$-chlorophyll, were added to further monitor the water quality of Xiashan Reservoir. As shown in Fig. 3, the concentrations of $\alpha$-chlorophyll at the entrance, middle and exit of Xiashan Reservoir were the highest during the high water period in 2003-2004, and the transparency in the low water period was better than in other water periods in 2003-2004. The annual average concentration of $\alpha$-chlorophyll at the entrance, middle and exit of Xiashan Reservoir was higher in 2004 than in 2003, and the annual average transparency at the entrance, middle and exit of Xiashan Reservoir was worse in 2004 than in 2003.

\subsubsection{Wei River}

As shown in Fig. 4 and Table 4, the water quality of the Wei River upstream the Xiashan Reservoir has gradually improved in the past decade. Unlike Zhigou, Guxian and Shiziyuan between 1995 and 2004, the concentration of COD $_{\mathrm{Cr}}$ at Jiutai gradually decreased between 1995 and 2004 (Fig. 4). This result clearly showed that water pollution control was effective in the urban area of Zhucheng County. In 2004, the water quality at these four monitoring sites (Zhigou, Jiutai, Guxian and Shiziyuan) almost met with the requirements of surface water environmental classification listed in Table 2. However, in 2004, only TP at Zhigou and Jiutai exceeded the regulated limitation values, TP and As at Guxian, and $\mathrm{BOD}_{5}, \mathrm{TP}, \mathrm{NH}_{3}-\mathrm{N}$ at Shiziyuan. TP was therefore the only parameter exceeded at all four monitoring sites of the Wei River upstream the Xiashan Reservoir in 2004.

\subsubsection{Qu River}

As shown in Fig. 5, the concentration of $\mathrm{COD}_{\mathrm{Cr}}$ slowly increased at both Pengwangdianzi and Jiagezhuang on the Qu River upstream

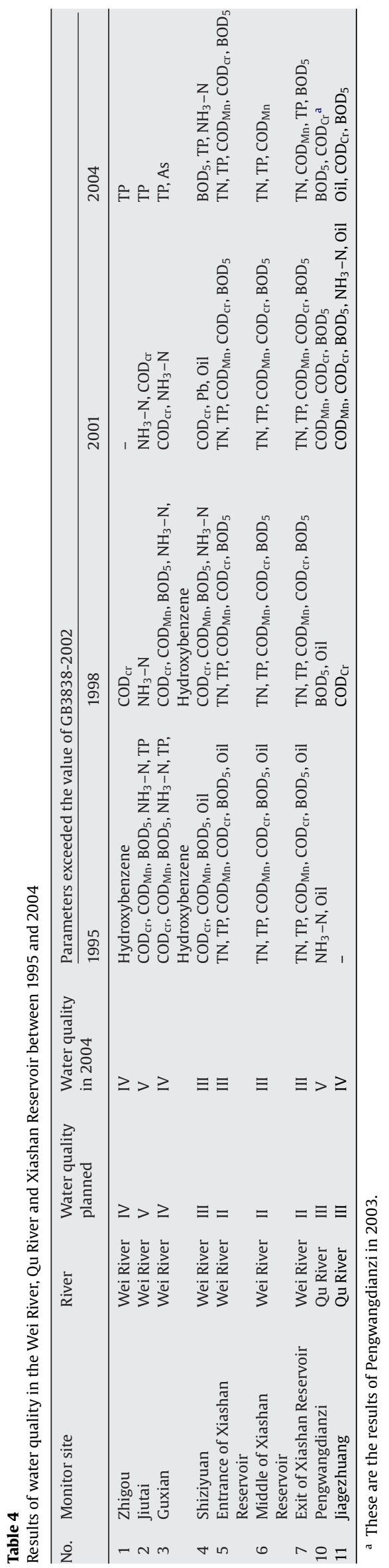



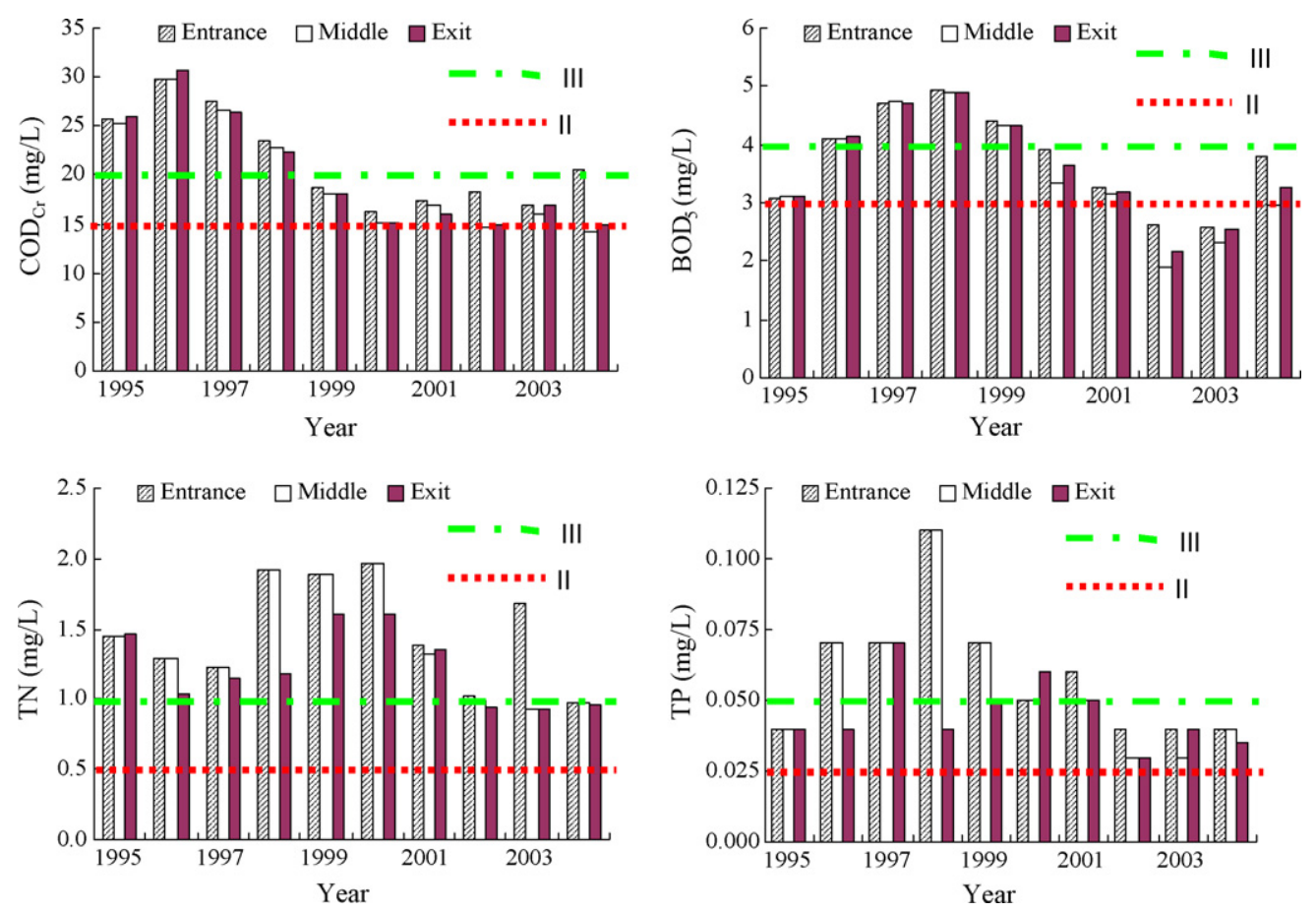

Fig. 2. Profiles of $\mathrm{COD}_{\mathrm{Cr}}$, BOD, $\mathrm{TN}$ and TP in Xiashan Reservoir between 1995 and 2004.

the Xiashan Reservoir between 1995 and 2004, and a peak of ammonia nitrogen occurred at both Pengwangdianzi and Jiagezhuang between 1998 and 2000. In 2004, the water quality at both Pengwangdianzi and Jiagezhuang did not meet Class III. Near the entrance of Xiashan Reservoir (only $8.0 \mathrm{~km}$ ) there is a big brewery in Jingzhi Town, and more effort is required to reduce pollutants discharged into the Qu River upstream the monitor site (Jiagezhuang).

\subsection{Industrial development and water use}

\subsubsection{Industrial production}

In the past decade, not only has industry in the upstream region of Xiashan Reservoir developed rapidly, but there has also been a shift in industrial structure, from the FPB as the major industry in 1995 to the CMAP in 2004 (Fig. 6 and Table 5). The total industrial
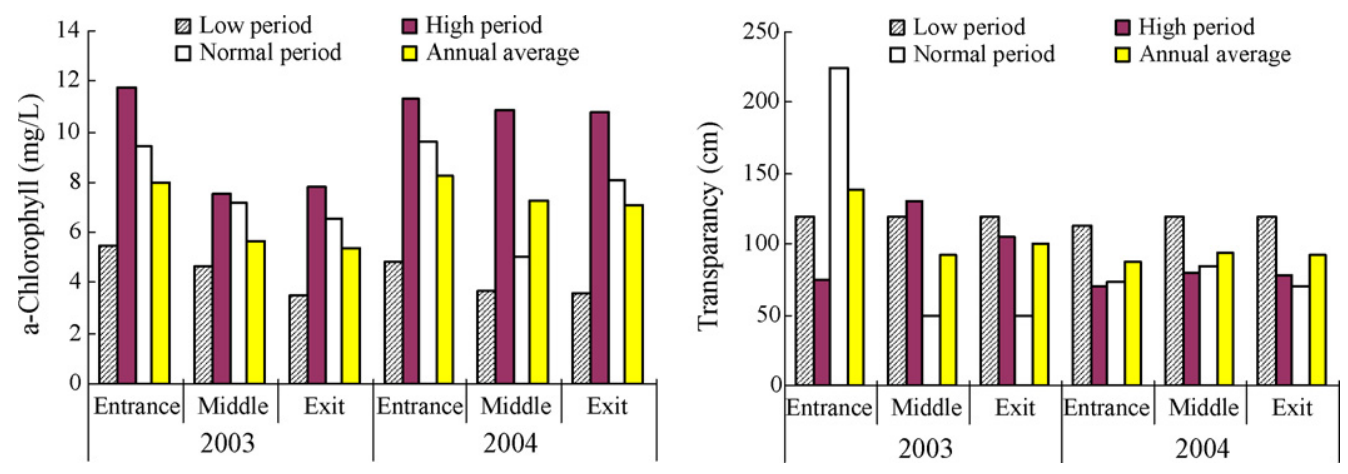

Fig. 3. Profiles of $\alpha$-chlorophyll and transparency of Xiashan Reservoir at different water periods between 2003 and 2004.
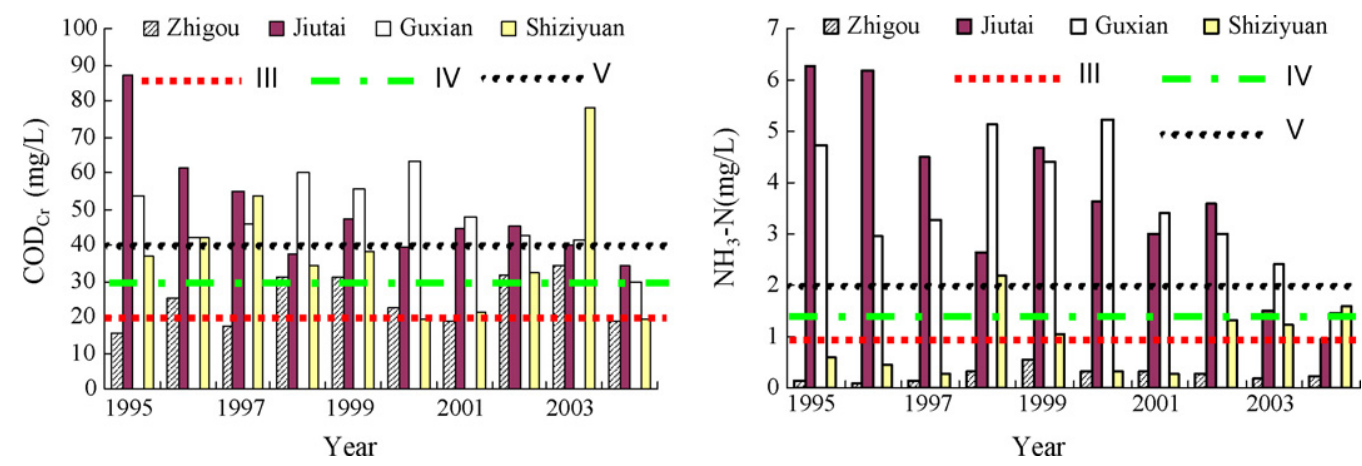

Fig. 4. Profiles of $\mathrm{COD}_{\mathrm{Cr}}$ and $\mathrm{NH}_{3}-\mathrm{N}$ at different monitor sites of Wei River upstream the Xiashan Reservoir between 1995 and 2004. 

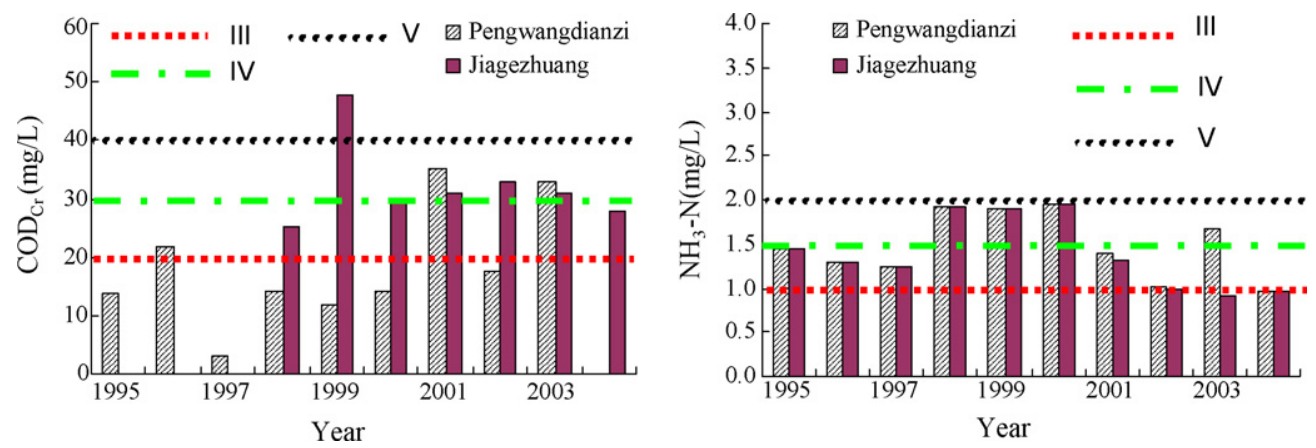

Fig. 5. Profiles of $\mathrm{COD}_{\mathrm{Cr}}, \mathrm{NH}_{3}-\mathrm{N}$ at different monitor sites of Qu River upstream the Xiashan Reservoir between 1995 and 2004.

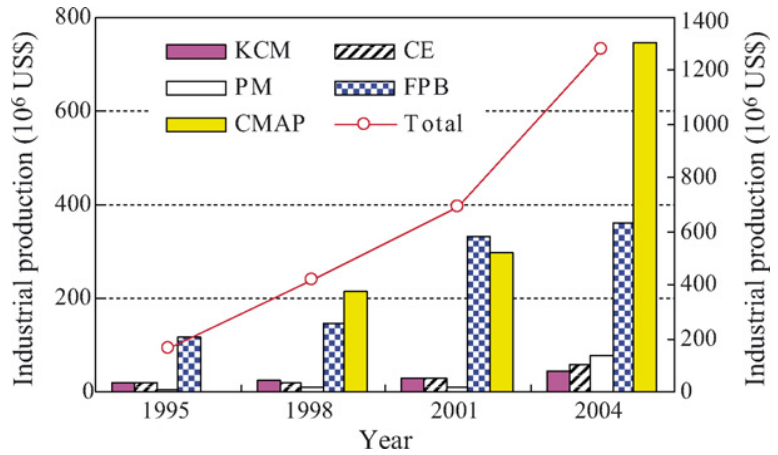

Fig. 6. Profiles of industrial production of key industries in the upstream region of Xiashan Reservoir between 1995 and 2004. production of the CMAP rose from US\$ 0.48 million in 1995 to US\$ 744.2 million in 2004, and accounted for only $0.3 \%$ in 1995 and $58.0 \%$ of total industrial production in 2004 . Correspondingly, the industrial production in 8 FPB plants fell from $72.5 \%$ in 1995 to $28.2 \%$ in 2004. Due to large water usage and heavy pollution, both the CE and PM experienced very slow development before 2001, but were accelerated between 2001 and 2004, i.e. the annual growth rates of the CE was $28.9 \%$ and PM industry was $116.4 \%$, however, KCM developed slowly and its annual growth rate was only $9.0 \%$.

\subsubsection{Water use}

Contrary to the substantial increase in total industrial production of these 19 plants between 1995 and 2004 (US\$ 163.66 million in 1995 and US\$1283.69 million in 2004), the total amount of water used by all 19 plants gradually decreased from 24.45 million $\mathrm{m}^{3}$ in

Table 5

Characteristics of industrial production, water usage and wastewater treatment of all 19 key plants in the upstream region of Xiashan Reservoir between 1995 and 2004

\begin{tabular}{|c|c|c|c|c|}
\hline Item & 1995 & 1998 & 2001 & 2004 \\
\hline Total Industrial production (million US\$) ${ }^{\mathrm{a}}$ & 163.66 & 415.69 & 692.35 & 1283.69 \\
\hline Chemical engineering (\%) & 11.4 & 5.1 & 3.9 & 4.5 \\
\hline Car making and its accessory processing (\%) & 0.3 & 51.8 & 42.9 & 58.0 \\
\hline Food processing and brewing (\%) & 72.5 & 35.6 & 47.6 & 28.2 \\
\hline Paper making (\%) & 3.2 & 2.0 & 1.1 & 5.9 \\
\hline Knitting and clothes making (\%) & 12.6 & 5.5 & 4.5 & 3.5 \\
\hline Total water usage $\left(\right.$ million $\mathrm{m}^{3}$ ) & 24.45 & 21.92 & 21.34 & 22.73 \\
\hline Chemical engineering (\%) & 53.5 & 39.2 & 38.4 & 36.9 \\
\hline Car making and its accessory processing (\%) & 0.1 & 1.6 & 1.1 & 3.8 \\
\hline Food processing and brewing (\%) & 40.7 & 33.4 & 35.1 & 28.4 \\
\hline Paper making (\%) & 4.9 & 21.7 & 21.4 & 23.7 \\
\hline Knitting and clothes making (\%) & 0.8 & 4.1 & 4.1 & 7.2 \\
\hline Total wastewater discharged (million $\mathrm{m}^{3}$ ) & 4.83 & 9.20 & 8.94 & 8.27 \\
\hline Chemical engineering (\%) & 23.6 & 21.1 & 16.1 & 8.9 \\
\hline Car making and its accessory processing (\%) & 0.2 & 1.8 & 1.5 & 3.0 \\
\hline Food processing and brewing (\%) & 58.2 & 36.5 & 40.1 & 34.0 \\
\hline Paper making (\%) & 14.9 & 32.2 & 35.0 & 41.0 \\
\hline Knitting and clothes making (\%) & 3.2 & 8.4 & 7.3 & 13.1 \\
\hline Percentage of industrial wastewater treated ${ }^{\mathrm{b}}(\%)$ & 82.8 & $162.5^{\mathrm{c}}$ & 98.2 & 98.0 \\
\hline Chemical engineering (\%) & 100.0 & $342.4^{\mathrm{c}}$ & 100.0 & 100.0 \\
\hline Car making and its accessory processing (\%) & 0.0 & 0.0 & 78.9 & 80.5 \\
\hline Food processing and brewing (\%) & 76.1 & $101.2^{\mathrm{c}}$ & 96.2 & 95.9 \\
\hline Paper making (\%) & 100.0 & $153.7^{c}$ & 100.0 & 100.0 \\
\hline Knitting and clothes making (\%) & 2.2 & 46.7 & 100.0 & 100.0 \\
\hline Total $\mathrm{COD}_{\mathrm{Cr}}$ discharged ( $\mathrm{t} /$ year) & 7227.5 & 3363.1 & 2121.58 & 1176.1 \\
\hline Chemical engineering (\%) & 2.51 & 5.33 & 22.43 & 11.05 \\
\hline Car making and its accessory processing (\%) & 0.00 & 0.26 & 0.63 & 4.31 \\
\hline Food processing and brewing (\%) & 76.89 & 38.26 & 21.35 & 23.70 \\
\hline Paper making (\%) & 19.29 & 47.05 & 50.20 & 28.65 \\
\hline Knitting and clothes making (\%) & 1.31 & 9.09 & 5.39 & 32.30 \\
\hline
\end{tabular}

a The value is calculated at the current price and transformed based on 1 US $\$=8.273 \mathrm{RMB}$.

b The value is calculated as $100 \times$ (the amount of total wastewater treated/the amount of total wastewater discharged).

c The amounts of wastewater treated in 1998 include not only industrial wastewater produced, but also domestic wastewater produced in the plant and adjacent community. 

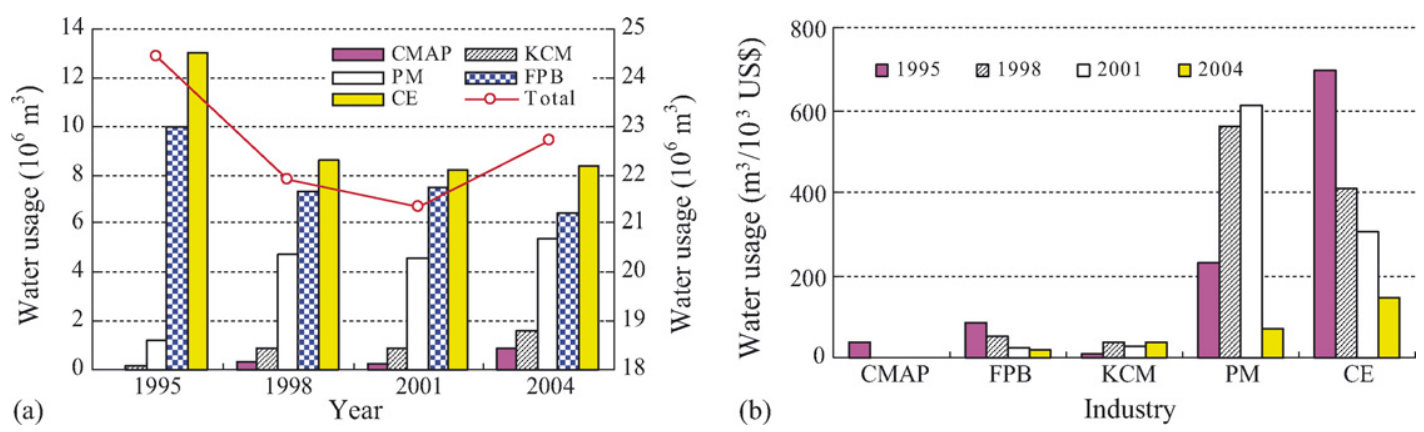

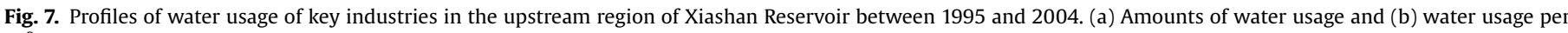
$10^{3}$ US\$.

1995 to 22.73 million $\mathrm{m}^{3}$ in 2004 (Table 5). The amount of freshwater usage of CE and FPB was much higher than that of other three industries, but their freshwater usage was reduced from 13.07 million $\mathrm{m}^{3}$ and 9.96 million $\mathrm{m}^{3}$ in 1995 to 8.39 million $\mathrm{m}^{3}$ and 6.46 million $\mathrm{m}^{3}$ in 2004, respectively (Fig. 7(a)). Compared with the decreasing water usage in both CE and FPB, the water usage of all other three industries, including PM, KCM and CMAP, experienced an increase between 1995 and 2004, especially PM which was higher than that of other two industries, increasing from 1.21 million $\mathrm{m}^{3}$ in 1995 to 5.39 million $\mathrm{m}^{3}$ in 2004. As listed in Table 5, the water used by CE and FPB as a percentage of the total water used by all 19 plants fell from 53.5\% and 40.7\% in 1995 to $36.9 \%$ and $28.4 \%$ in 2004, respectively, but that of PM and KCM rose from $4.9 \%$ and $0.8 \%$ in 1995 to $23.7 \%$ and $7.2 \%$ in 2004 , respectively.

For all 19 key plants, the total water usage per thousand US\$ decreased step by step, from $149.4,52.7,30.9$ and $17.7 \mathrm{~m}^{3} / 10^{3}$ US\$ in 1995, 1998, 2001 and 2004, respectively. Except for KCM, the decreasing water usage per $10^{3}$ US\$ occurred in all four other industries (Fig. 7(b)). Between 1995 and 2004, the water usage per $10^{3}$ US\$ of CE and FPB was greatly reduced, from $697.7 \mathrm{~m}^{3} / 10^{3}$ US\$ in 1995 to $17.7 \mathrm{~m}^{3} / 10^{3}$ US\$ in 2004 for CE, and from $83.9 \mathrm{~m}^{3} / 10^{3}$ US\$ in 1995 to $17.9 \mathrm{~m}^{3} / 10^{3}$ US\$ in 2004 for FPB. However, there was a sharp increase in water usage per $10^{3}$ US\$ in PM industry during 1995-2001 (from $232.7 \mathrm{~m}^{3} / 10^{3}$ US\$ in 1995 to $610.1 \mathrm{~m}^{3} / 10^{3}$ US\$ in 2001), and a rapid decrease in this industry (from $610.1 \mathrm{~m}^{3} / 10^{3}$ US\$ in 2001 to $71.2 \mathrm{~m}^{3} / 10^{3}$ US\$ in 2004) (Fig. 7(b)). In addition, a rapid growth of water usage per $10^{3}$ US\$ occurred in KCM, from $9.3 \mathrm{~m}^{3} / 10^{3}$ US\$ in 1995 to $36.3 \mathrm{~m}^{3} / 10^{3}$ US\$ in 2004 .

\subsection{Industrial wastewater treatment}

\subsubsection{Industrial wastewater discharged}

As shown in Fig. 8(a) and Table 5, PM and FPB in 2004 were the top two industries discharging industrial wastewater

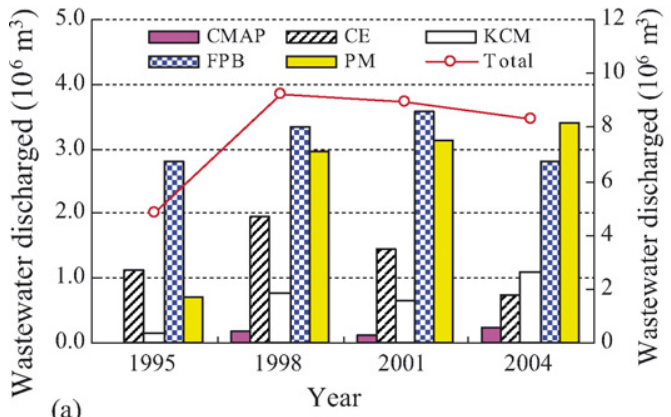

(a) (b) wastewater discharged per $10^{3}$ US\$.
(3.39 million $\mathrm{m}^{3}$ and 2.82 million $\mathrm{m}^{3}$, respectively), and accounted for $41.0 \%$ and $34.0 \%$, respectively, of the total industrial wastewater discharged by all 19 key plants. Notably, a sharp increase in industrial wastewater discharged by PM occurred between 1995 and 1998. The peak of industrial wastewater discharged by CE and FPB occurred in different years, i.e. 1.94 million $\mathrm{m}^{3}$ for CE in 1998 and 3.59 million $\mathrm{m}^{3}$ for FPB in 2001, and then decreased for both in the

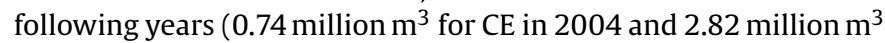
of FPB in 2004). However, an increasing trend was observed in the industrial wastewater discharged of the other three industries (CMAP, KCM and PM).

For all 19 plants, the total wastewater discharged per $10^{3}$ US\$ gradually decreased between 1995 and 2004, from $29.5 \mathrm{~m}^{3} / 10^{3}$ US\$, $22.2 \mathrm{~m}^{3} / 10^{3}$ US\$, $12.9 \mathrm{~m}^{3} / 10^{3}$ US\$ and $6.5 \mathrm{~m}^{3} / 10^{3}$ US\$ in 1995, 1998, 2001 and 2004, respectively. As shown in Figs. 7(b) and 8(b), the trend in industrial wastewater discharged per $10^{3}$ US\$ is the same as the decreasing trend in water usage per $10^{3}$ US\$, decreasing from $22.2 \mathrm{~m}^{3}$ wastewater discharged per $10^{3}$ US $\$$ in 1995 to $6.5 \mathrm{~m}^{3}$ wastewater discharged per $10^{3}$ US\$ in 2004. As an emerging and new industry, the water utilization rate of CMAP was promoted, decreasing from $24.8 \mathrm{~m}^{3} / 10^{3}$ US\$ in 1995 to $0.3 \mathrm{~m}^{3} / 10^{3}$ US\$ in 2004 . Except for increase of KCM (from $7.4 \mathrm{~m}^{3} / 10^{3}$ US\$ in 1995 to $24.1 \mathrm{~m}^{3} / 10^{3}$ US\$ in 2004), a rapid decrease in the wastewater discharged per $10^{3}$ US $\$$ was observed in the other four industries (Fig. 8(b)).

\subsubsection{Industrial wastewater treatment}

Fig. 9 clearly shows an inverted U-shape relationship between IWDQ and GDP per capita, and its regression analysis shows that coefficient $b_{2}$ is negative which verifies an existence of EKC between industrial wastewater qualified discharge and GDP per capita. But the total industrial wastewater discharge declined with increasing of GDP per capita, and EKC does not apply it.

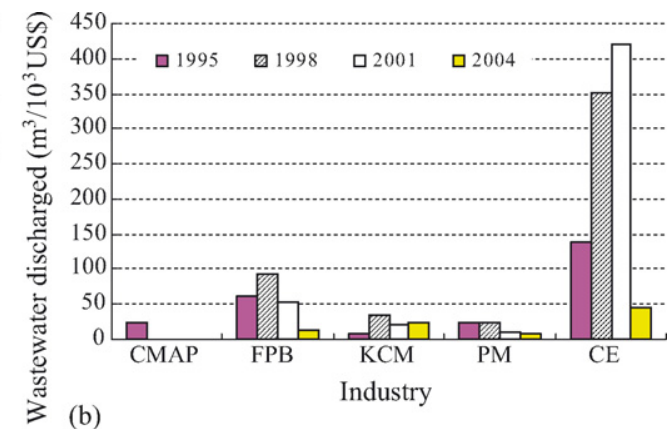

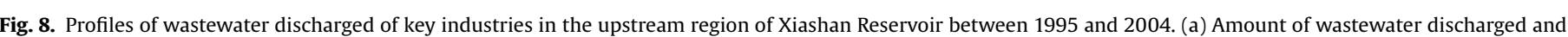




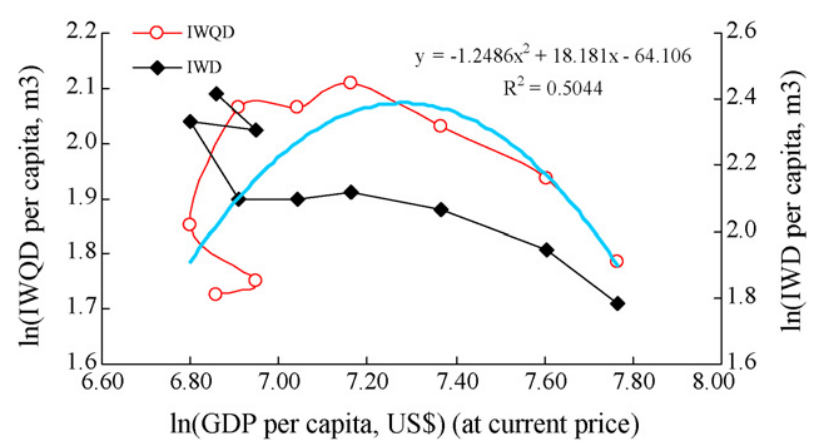

Fig. 9. Relationship of industrial wastewater and GDP per capita in the upstream region of Xiashan Reservoir between 1997 and 2005 (IWD = industrial wastewater discharge; IWQD = industrial wastewater qualified discharge).

In order to protect Xiashan Reservoir, most plants have built their own wastewater treatment facilities. Between 1995 and 2004, industrial wastewater treatment improved in these 19 key plants, the rate of industrial wastewater treatment increased from $82.8 \%$ in 1995 to $98.0 \%$ in 2004 (Table 5). Moreover, all industrial wastewater discharged in both CE and PM was treated between 1995 and 2004. Although little wastewater discharged in CMAP before 2000 was treated, wastewater treatment improved after 2000 and then increased to $80.5 \%$ in 2004 . Similar to industrial wastewater treatment in CMAP, the wastewater treatment rate of KCM rose from $2.2 \%$ in 1995 to $100 \%$ in 2001 . During the past decade, FPB maintained a high wastewater treatment rate, gradually increasing from $76.1 \%$ in 1995 to $95.9 \%$ in 2004 . Before 2000 , domestic wastewater in plants and their adjacent communities was also collected and treated by the industrial wastewater facilities of some industries, such as CE, FPB and PM, and this phenomenon thus resulted in 100\% wastewater treatment rates in these industries from 1998 to 2000 (Table 5).

\subsection{Pollutant discharge}

A great reduction in total $\mathrm{COD}_{\mathrm{Cr}}$ discharged was observed between 1995 and 2004, the amount discharged in 2004 (1176.71 t) was only $16.3 \%$ of that in 1995 (7227.5 t) (Fig. 10(a) and Table 5). Such a sharp reduction is mainly attributed to FPB and PM with $96.18 \%$ of the total $\mathrm{COD}_{\mathrm{Cr}}$ discharged from these two industries in 1995, but only $51.35 \%$ in 2004 . In contrast to the sharp reduction of $\mathrm{COD}_{\mathrm{Cr}}$, a rapid increase in $\mathrm{COD}_{\mathrm{Cr}}$ discharge occurred in KCM (Fig. 9(a)), from $94.4 \mathrm{t}$ in 1995 to $379.83 \mathrm{t}$ in 2004, and resulted in three industries (PM, KCM and FPB) becoming the major sources (84.65\%) of $\mathrm{COD}_{\mathrm{Cr}}$ discharged. Although the amount of $\mathrm{COD}_{\mathrm{Cr}}$ discharged from CE decreased between 1995 and 2004, its percentage rose from $2.51 \%$ in 1995 to $11.05 \%$ in 2004 .

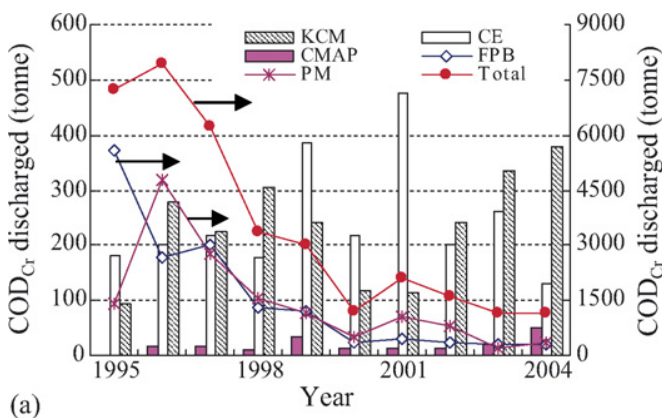

The lowest $\mathrm{COD}_{\mathrm{Cr}}$ discharged per million US\$ in all five key industries between 1995 and 2004 was for CMAP, only ranging from 0.04 to $0.07 \mathrm{t} / \mathrm{million}$ US\$, and the highest was for PM, as high as $268.20 \mathrm{t} / \mathrm{million}$ US\$ in 1995 . Due to innovative processes (e.g., abolishing pulp making from wheat stalks instead of using waste paper as the raw materials for PM) and enhanced wastewater treatment (e.g., primary wastewater treatment process replaced by secondary wastewater treatment for $\mathrm{FPB}$ ), the $\mathrm{COD}_{\mathrm{Cr}}$ discharged per million US\$ for PM and FPB was sharply reduced between 1995 and 2004 (Fig. 9(a)). However, an increase in $\mathrm{COD}_{\mathrm{Cr}}$ discharged per million US\$ occurred in KCM and resulted in this industry becoming the highest $\mathrm{COD}_{\mathrm{Cr}}$ discharged per million US\$, instead of PM in 2004 (Fig. 9(b)).

\section{Discussion}

Although the water quality of Xiashan Reservoir was only Class IV between 1998 and 2000 mainly because of TN, over $1.5 \mathrm{mg} / \mathrm{L} \mathrm{TN}$, much higher than the requirements of Class II (Fig. 2), the water quality of Xiashan Reservoir has gradually improved in the past decade (1995-2004) and met the requirements of Class III in 2004. However, it is notable that the water quality of Xiashan Reservoir still has not reached the planned Class II. According to Environmental quality standard of surface water of China (GB3838-2002), Class III is the lowest limitation for drinking surface water. Hence, it is clear that efforts made by local government and plants have been effective in the past decade, and much more efforts should be made to improve water quality of Xiashan Reservoir so as to reach Class II in the very future. Although the concentrations of organic pollutants such as $\mathrm{COD}_{\mathrm{Cr}}, \mathrm{BOD}_{5}$ and $\mathrm{COD}_{\mathrm{Mn}}$ have gradually decreased in the past decade and almost met Class II in 2004, more attention should be paid to nutrient pollution from nitrogen and phosphorus in order to avoid eutrophication of Xiashan Reservoir in the near future. Hence, more efforts should be made to further reduce organic pollutants and nutrients discharged into water bodies in order to make Xiashan Reservoir a stable water source for Weifang sustainable development in the future.

Due to the downstream of urban development of Zhucheng County, the water quality at Jiutai (Site 2) before 2002 was worse than Class V (Fig. 4), but has gradually improved since 2002. This result clearly shows the effective enhancement of water pollution control in the urban area carried out by local governments. As the last monitoring site on the Wei River before Xiashan Reservoir, more attention is needed to the sharp increase in ammonia nitrogen at Shiziyuan (Site 4) since 2001. In addition, the $\mathrm{COD}_{\mathrm{Cr}}$ at Zhigou (Site 1) on the Wei River slowly increased between 1995 and 2004, although the concentration of ammonia nitrogen at Zhigou was very low. This phenomenon may be caused by agricultural diffuse pollution, whose impacts and contribution to water pollution in the Wei River need further study.

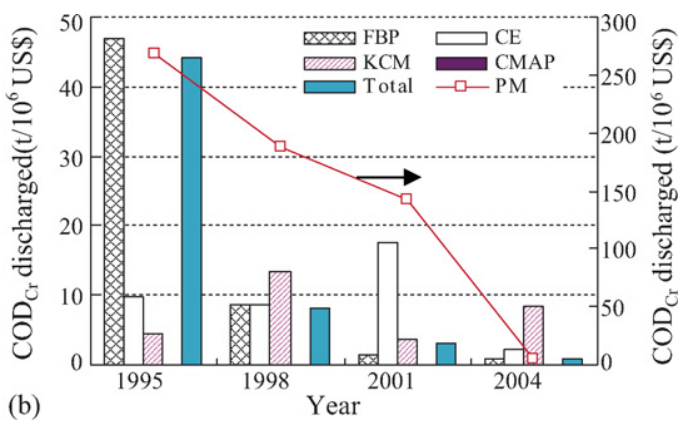

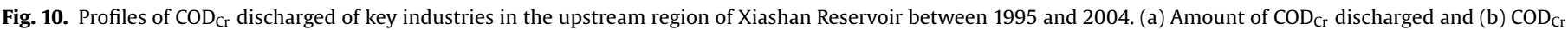
discharged per $10^{6}$ US\$. 
Historically, industrial pollution was the main contributor to the water pollution load. Although these industrial pollution sources have to some extent stabilized or even been reduced, urbanization has partially off set these improvements. By comparing changes in water quality in the Wei River and Xiashan Reservoir with variations in industrial wastewater and organic pollutant discharged by these five key industries, it can be inferred that, between 1995 and 2004, industrial wastewater discharged was the main factor affecting the water quality of Xiashan Reservoir in the early stages, and that domestic wastewater discharged from the urban area of Zhucheng County represented the key factor in the later stages. In the early stages, organic pollutants from industries were the main factor impacting on water quality of the Wei River and Xiashan Reservoir because of the small scale urban area, low population in the urban area, and lack of industrial wastewater treatment facilities. Along with fast urbanization, domestic wastewater discharged from the urban area of Zhucheng County gradually had more impact on water quality of water bodies because of improvements in industrial wastewater treatment, a rapid increase in population in the urban area, and a lack of a municipal wastewater treatment plant. According to the investigation results of water pollution sources in 2002 (RCEES, 2005), the total pollutants $\left(\right.$ COD $_{\mathrm{Cr}}$ of $4419.40 \mathrm{t} / \mathrm{year}$ and $\mathrm{NH}_{3}-\mathrm{N}$ of $441.90 \mathrm{t} /$ year) discharged from municipal wastewater into the $\mathrm{Qu}$ River were much higher than those $\left(\mathrm{COD}_{\mathrm{Cr}}\right.$ of $3811.74 \mathrm{t} /$ year and $\mathrm{NH}_{3}-\mathrm{N}$ of $267.51 \mathrm{t} /$ year) from industrial wastewater. Water pollution of Xiashan Reservoir showed characteristics of two-stage organic pollutant and nutrient contamination between 1995 and 2004. First, organic pollutants from industrial wastewater discharged were the main factor in the early stage, second, nutrient pollutants were the major factor. Therefore, these results indicate that domestic wastewater pollution control should be the most of target in the near future.

According to the regulations, the water quality at Pengwangdianzi (Site 10) and JiageZhuang (Site 11) on the Qu River should be Class III. Unfortunately, the slow increase in $\mathrm{COD}_{\mathrm{Cr}}$ at these two sites resulted in water quality below Class III. The distance between Jiagezhuang (Site 11) and the entrance of Xiashan Reservoir (Site 5) is only $8 \mathrm{~km}$. Due to historical reason, the big brewery plays a significant role in socioeconomic development of Jingzhi Town. Local government and the brewery have made great efforts to reduce pollutants discharging into the Qu River, e.g., the $\mathrm{COD}_{\mathrm{Cr}}$ discharged was greatly reduced from $4955.9 \mathrm{t}$ in 1995 to $121.68 \mathrm{t}$ in 2004, but much work is still needed, such as building a new municipal wastewater treatment plant planned by the local government to treat domestic wastewater.

Results of the industrial development between 1995 and 2004 showed that not only had industry developed rapidly, but also that there was a big shift in industrial structure, from FPB as the major industry in 1995 to CMAP in 2004. In other words, there was a transfer from low technology, low industrial production, high water consumption and high pollution industries to high technology, high industrial production, low water consumption and low pollution industries. The big shift of industrial structure may be caused by several factors, such as more and more stringent environmental regulations and enforcement, car industry emerging along with rapid urbanization and economic development, and government guidance. Although protection of water sources poses limitation on industrial development in the upstream region of Xiashan Reservoir to some extent, it has to some extent improved industrial structure and promoted wider application of new technologies.

Contrary to the rapid rise in industrial production of all 19 key plants, the total amount of water used by these plants decreased by 1.72 million $\mathrm{m}^{3}$ between 1995 and 2004, mainly as a result of a reduction in water usage in CE and PM. Investigations showed that the decrease of water usage was the result of guidance by local government and recycling of industrial cooling water (SPDWR, 2004). Although the water usage efficiencies of the five key industries improved very much between 1995 and 2004, especially CE, the industrial water usage per thousand US\$ were still very high in 2004 , i.e. $146.1 \mathrm{~m}^{3} / 10^{3}$ US $\$$ for CE and $36.3 \mathrm{~m}^{3} / 10^{3}$ US $\$$ for KCM. The reported water usage of the chemical engineering industry in the USA, Canada and Mexico was $31.7 \mathrm{~m}^{3} / 10^{3}$ US\$, and that of China was $110.7 \mathrm{~m}^{3} / 10^{3}$ US\$ (NDRC, 2005). In 1997, the water usage of the textile industry in Beijing was as low as $24.4 \mathrm{~m}^{3} / 10^{3}$ US\$ (Wang et al., 2005a). Therefore, there is still great potential to improve water utilization efficiency of these industries in the upstream region of Xiashan Reservoir.

Corresponding with decreased water usage, the total wastewater discharged in 2004 was only a little higher than that in 1995. The total amount of industrial wastewater discharged from the 19 key plants reached a maximum $\left(9.20\right.$ million $\left.^{3}\right)$ in 1998 , and then slowly decreased to 8.27 million $\mathrm{m}^{3}$ in 2004 . Between 1995 and 1998, three industries (CE, FPB and PM) not only consumed large amounts of water, but also discharged large amounts of industrial wastewater. Along with enhancement of water protecting measure for Xiashan Reservoir by local government, industrial water usage efficiencies were improved and their wastewater treatment was enhanced. Due to a combination of rapidly increasing industrial production, a shift in industrial structure, innovation of processes and enhancement of industrial wastewater treatment, industries not only decreased wastewater discharged per thousand US\$ of all 19 key plants, but also reduced pollutants such as $\operatorname{COD}_{\mathrm{Cr}}$ discharged into water bodies.

The EKC is an essentially empirical phenomenon, and useful to study the relationship between economic development and environment issues, such as environmental quality, industrial water use, pollutant load contribution (Jia et al., 2006; Okadera et al., 2006; Tsuzuki, 2006; Liu et al., 2007). In this study, the standard EKC model was used to investigate the existence of EKC between economic development and industrial wastewater discharge in the upstream region of Xiashan Reservoir. Results verified an inverted U-shape EKC relationship between IWDQ and GDP per capita. This result also confirms that spreading and improving industrial wastewater treatment is helpful for water pollution control and source water protection. However, further study is needed in testing EKC existence in the upstream region of Xiashan Reservoir.

Source water protection represents both challenges and opportunities for the upstream region of the water source. In this case, there are many challenges for protecting Xiashan Reservoir, such as more strict requirements for environment quality and more limitations on some industrial development, but there are also lots of opportunities for industrial development, e.g., a shift and upgrade of industries, wide spread innovative technologies, and improvement in water utilization and enhancement of wastewater treatment. In order to much better protect Xiashan Reservoir, to save water and promote industrial development in the upstream region of Xiashan Reservoir in the future, it is necessary to further improve industry structure, to spread cleaner production and application of water saving technologies, to encourage innovation of processes according to the successful experience of Xiashan Reservoir protection and industry development in the upstream region in the past decade.

\section{Conclusions}

Through investigating water quality of Xiashan Reservoir and industrial development in the upstream region of Xiashan Reservoir between 1995 and 2004, it is found that neither the indus- 
trial development in the upstream region was heavily limited by protecting Xiashan Reservoir, nor the water quality of Xiashan Reservoir was worsening because of rapid industrial development. Therefore, water source protection could be harmonized with the industrial development in the upstream region of water source, through improving industrial structure, spreading cleaner production, boosting water utilization efficiency, and enhancing industrial wastewater treatment. Conclusions are made as follows.

The water quality of Xiashan Reservoir gradually improved between 1995 and 2004 and met Class III in 2004, although it never reached Class II as planned in the past decade. It is noted that TN and TP were still much higher than the regulated limitations of Class II, and more efforts should be made on nutrients removal in the wastewater treatment. As two upstream rivers, both the Wei and Qu Rivers play a significant role in protecting Xiashan Reservoir. Between 1995 and 2004, the water quality of the Wei River upstream the Xiashan Reservoir slowly improved, unfortunately, that of the Qu River upstream the Xiashan Reservoir was worsening, i.e. as worse as Class IV in 2004.

Rapid industrial development and big shift of industrial structure occurred in the upstream region of Xiashan Reservoir. The total industrial production of these 19 key plants in 2004 was nearly 8 times of that in 1995, and the industry transferred from FPB as the major industry in 1995 to CMAP in 2004. Different from rapid increase of the total industrial production, the amount of water used by all five industries in 2004 was lower than that in 1995 because of increase of water utilization and shift of industrial structure. In 2004, three industries (CE, FPB and PM) consumed $89 \%$ of the total water used by all five industries.

Results verified an inverted U-shape EKC relationship between IWDQ and GDP per capita. The total discharged wastewater in 2004 was a little higher than that in 1995, but its increasing rate was much lower than that of industrial production. In 2004, three industries (FPB, PM and KCM) discharged $88.1 \%$ of the total discharged wastewater, in which FPB and PM contributed to 75\%. The decrease of wastewater discharged per thousand US\$ was much more in CE than that of other industries. Between 1995 and 2004, a great reduction occurred in the total $\mathrm{COD}_{\mathrm{Cr}}$ discharged from all five industries, and mainly attributed to the reduction of $\mathrm{COD}_{\mathrm{Cr}}$ discharged from FPB and PM.

\section{Acknowledgements}

This study was financially supported by the Weifang Environmental Protection Agency, National Natural Science Foundation of China (No. 70403014, No. 70325002) and Chinese Academy of Sciences (KZCX3-SW-438). We are greatly in debt to the local governments for help provided during our investigations.

\section{References}

Abu-Zeid MA. Water and sustainable development: the vision for world water, life and the environment. Water Policy 1998;1:9-19.

Clark RM, Goodrich JA, Lykins Jr BW, Neal JR. Evaluating the effects of upstream dischargers on downstream water supplies: a source water protection model. Aqua: Journal of Water Services Research and Technology 1998;47(5):215-22.

De Groot HLF, Withagen CA, Zhou ML. Dynamics of China's regional development and pollution: an investigation into the environmental Kuznets curve. Environment and Development Economics 2004;9:507-37.

Du X, Peng WQ. Analysis of water quality of urban water sources and its protection measures. Technical Supervision in Water Resources 2004;12(3):50-2 (Chinese).

Falkenmark M. Competing freshwater and ecological services in the river basin perspective: an expanded conceptual framework. Water International 2000;25(2):72-177.

Ivey JL, de Loë R, Kreutzwiser R. Planning for source water protection in Ontario. Applied Geography 2006a;26:192-209.

Ivey JL, de Loë R, Kreutzwiser R, Ferreyra C. An institutional perspective on local capacity for source water protection. Geoforum 2006b;37:944-57.
Janosova B, Miklankova J, Hlavinek P, Wintgens T. Drivers for wastewater reuse: regional analysis in the Czech Republic. Desalination 2006;187:103-14.

Jia SF, Yang H, Zhang SF, Wang L, Xia J. Industrial water use Kuznets curve: evidence from industrialized countries and implications for developing countries. Journal of Water Resources Planning and Management 2006;132(3):183-91.

Li YL, Zhao CY. Sustainable utilization of water resources in Shandong province. Journal of Chongqing Normal University (Natural Science Edition) 2003;20(4):63-7 (Chinese).

Li JX, Liao WG, Chen MJ, Wang H. Economic loss estimation of water pollution in China. China Water Resources A 2003;11:63-6 (Chinese).

Liu CM, Chen ZK, editors. Water strategy for China's sustainable development report 2: current state of China's water resources and the outlook of future demand and supply. Beijing, China: China Water Resources and Hydropower Press; 2001. pp. 83-84, 148-154 (Chinese).

Liu JG, Diamond J. China's environment in a globalizing world. Nature 2005;435:1179-86.

Liu XZ, Heiligb GK, Chen JM, Heino M. Interactions between economic growth and environmental quality in Shenzhen, China's first special economic zone. Ecological Economics 2007;62:559-70.

The Ministry of Water Resources of China (MWR). Water resources bulletin in 2000. http://www.shuiziyuan.mwr.gov.cn/gongshi/show_gazettea.asp?id=79. Cited October 8, 2001 (Chinese)

The Ministry of Water Resources of the People's Republic of China (MWR). China country report on sustainable development-water resources. http://www.mwr.gov.cn/english1/pdf/china2003.pdf. 2004 (Chinese).

The Ministry of Water Resources of China (MWR). Water resources bulletin in 2004. China Water Resources and Hydropower Press. Beijing, China, 2005 (Chinese).

National Research Council. Watershed management for source water protection. In: Watershed management for potable water supply: assessing the New York City strategy. National Academy Press, Washington, DC, 2000; pp. 130-157.

National Development and Reform Committee of China (NDRC). Status quo, problems and countermeasures of water saving in chemical engineering industry. http://www.ndrc.gov.cn/hjbh/jnjs/t20051206_52640.htm. Cited December 03, 2005 (Chinese).

Okadera T, Watanabe M, Xua K. Analysis of water demand and water pollutant discharge using a regional input-output table: an application to the City of Chongqing, upstream of the Three Gorges Dam in China. Ecological Economics 2006;58(2):221-37.

Pionke HB, Gburek WJ, Sharpley AN. Critical source area controls on water quality in an agricultural watershed located in the Chesapeake Basin. Ecological Engineering 2000;14(4):325-35.

Pires M. Watershed protection for a world city: the case of New York. Land Use Policy 2004;21:161-75.

Postel SL, Thompson Jr BH. Watershed protection: capturing the benefits of nature's water supply services. Natural Resources Forum 2005;29(2):98-108.

Research Center for Eco-Environmental Sciences (RCEES). Chinese Academy of Sciences Report: Protection of water source in Xiashan Reservoir, 2005 (Chinese).

Shandong Provincial Department of Water Resources (SPDWR). The quota of irrigated water use in Shandong Province. http://www.sdwr.gov.cn/Lists/ cszy/szy/default3.aspx?entityid=fL330903\&fid=3. Cited December 14, 2004 (Chinese).

Stern DI. The rise and fall of the environmental Kuznets curve. World Development 2004;32(8):1419-39.

Sullivan TJ, Snyder KU, Gilbert E, Bischoff JM, Wustenberg M, Moore J, et al. Assessment of water quality in association with land use in the Tillamook Bay Watershed, Oregon, USA. Water Air and Soil Pollution 2005;161(1-4):3-23.

Tang KW, Wang Y. Analysis of water quality in city water sources of China. Water Resources Protection 2001(2):30-1 (Chinese).

The Second World Water Forum. Ministerial declaration of the Hague on water security in the 21st Century, 2000. http://www.waternunc.com/gb/secwwf12.htm.

Timmer DK, de Loë RC, Kreutzwiser RD. Source water protection in the Annapolis Valley, Nova Scotia: lessons for building local capacity. Land Use Policy 2007;24:187-98.

Tsuzuki Y. An index directly indicates land-based pollutant load contributions of domestic wastewater to the water pollution and its application. Science of the Total Environment 2006;370:425-40.

Varis $\mathrm{O}$, Vakkilainen P. China's 8 challenges to water resources management in the first quarter of the 21st Century. Geomorphology 2001;41:93-104.

Wang SC. Promote sustainable social and economic development with sustainable utilization of water resources. Address at the Ministerial Conference of the 3rd World Water Forum, March 22, 2003, Kyoto. http://www.mwr. gov.cn/english1/20040817/38869.asp.

Wang CS, Pan LB. Water environment protection of water source in the middle line of South to North Transfer. Geography and Territorial Research 1999;15(3):52-5 (Chinese).

Wang H, Wang DX, Ni HZ, Lai HL. Water demand for development of industry in China. Journal of Hydraulic Engineering 2004;4:109-13 (Chinese).

Wang DX, Wang H, Ni HZ, Ma J. Analysis and assessment of water use in different sectors of national economy. Journal of Hydraulic Engineering 2005a;36(2):167-73 (Chinese).

Wang Y, Dong Y, Tan J. Enhancement of protecting urban water source in Weifang. Shandong Hydraulic Engineering 2005b;6:24 (Chinese).

Weifang Statistics Bureau. Statistics Yearbook of Weifang. Statistics Publisher of China, 1995-2005 (Chinese). 
World Bank Report. China-Country water resources assistance strategy. Report 27208, 2003. http://www-wds.worldbank.org/servlet/WDS_IBank_ Servlet?pcont=details\&eid=000012009_20031110115308.

World Bank Report. China water quality management: policy and institutiona considerations. Report 37752, 2006. http://www-wds.worldbank.org/external/ default/WDSContentServer/WDSP/IB/2006/10/18/000310607_20061018111318/ Rendered/PDF/377520CHA01Wat1management001PUBLIC1.pdf.

Xu OX, Che Y, Yang K. Comparative study on area of water source management system between China and USA. Shanghai Environmental Sciences 2003;22(7). pp. 487-490, 498 (Chinese).
Zhang WG, Yang ZF, Yi F, Wang X, Li QJ. Regional economic development pattern and sustainable use of water resources. China Soft Science 2002;9:87-92 (Chinese).

Zhou Y, Richard SJ. Implications of desalination for water resources in China-an economic perspective. Desalination 2004;164:225-40.

Zhu HF, Ruan RL. Exploitation of water sources in the estuary of Yangtze River and its countermeasures. China Water \& Wastewater 2004;20(4):91-3 (Chinese). 